\title{
Merkel Cell Carcinoma pM1b TNM Finding v7
}

National Cancer Institute

\section{Source}

National Cancer Institute. Merkel Cell Carcinoma pM1b TNM Finding v7. NCI Thesaurus.

Code $C 88535$.

Merkel cell carcinoma with metastasis to lung. (from AJCC 7th Ed.) 